\title{
Water resource development plan for Dindori : A tribal district
}

\author{
R.N. Shrivastava and R.K. Nema
}

Received : 21.05.2018; Revised : 11.08.2018; Accepted : 27.08.2018

See end of the Paper for authors' affiliation

Correspondence to :

R.N. Shrivastava

Department of Soil and Water

Engineering, College of

Agricultural Engineering, Jawaharlal Nehru Krishi Viswa Vidyalaya, Jabalpur (M.P.) India

Email : dr.rnshrivastava@ gmail.com
- ABSTRACT : Dindori is a trible district of Madhya Pradesh situated in Upper Narmada Basin. The district is far away from agricultural development. Only traditional farming with limited irrigated area $(1.2 \%)$ is being practiced. In order to improve this situation a detailed water resource plan is prepared as water is the key resource. First net availability of ground water is estimated and possible numbers of ground water structures are worked out and resulting increase in irrigated area is also determined. Similarly the surface water resources are also taken in account. Looking to all this suitable changed cropping pattern for the district is also suggested. In order to recharge ground water possible location for recharge structures are found out for each block of the district as per CGWB guide lines.

- KEY WORDS : Water resource, River basin, Ground water, Surface water, Ground water potential, Irrigation intensity, Ground water recharge, Ground water structure, Ground water development, Water resource planning

- HOW TO CITE THIS PAPER : Shrivastava, R.N. and Nema, R.K. (2018). Water resource development plan for Dindori : A tribal district. Internat. J. Agric. Engg., 11(2) : 314-319, DOI: 10.15740/HAS/IJAE/11.2/314-319. Copyright@2018: Hind Agri-Horticultural Society. 